ISSN 2076-3387

www.mdpi.com/journal/admsci

Article

\title{
Leadership and Knowledge Management in an E-Government Environment
}

\author{
Sherry D. Ryan ${ }^{1, *}$, Xiaoni Zhang ${ }^{2}$, Victor R. Prybutok ${ }^{1}$ and Jason H. Sharp ${ }^{3}$
}

1 Information Technology and Decision Sciences, College of Business, University of North Texas, 1155 Union Circle \#305249, Denton, TX 76203-5017, USA; E-Mail: victor.prybutok@unt.edu

2 Department of Business Informatics, College of Informatics, Northern Kentucky University, Nunn Dr., Highland Heights, KY 41099, USA; E-Mail: zhangx@nku.edu

3 Department of Computer Information Systems, College of Business, Tarleton State University, Box T-0170, Stephenville, TX 76402, USA; E-Mail: jsharp@tarleton.edu

* Author to whom correspondence should be addressed. E-Mail: sherry.ryan@unt.edu.

Received: 30 November 2011; in revised form: 18 January 2012 / Accepted: 27 January 2012 /

Published: 3 February 2012

\begin{abstract}
The Malcolm Baldrige National Quality Award (MBNQA) is well known to assess quality and business processes in a variety of sectors, including government. In this study, we investigate the relationship between aspects of the MBNQA's leadership triad and knowledge management in an e-government context. Specifically, we survey 1,100 employees of a medium-sized city government in the United States to investigate the relationship between leadership triad components, leadership strategic planning, and customer/market focus, with knowledge management. Our results show that these components are significantly related to knowledge management and are important in the delivery of e-government applications to the citizenry.
\end{abstract}

Keywords: e-government; knowledge management; leadership strategic planning; customer and market focus; The Malcolm Baldrige National Quality Award; MBNQA

\section{Introduction}

Governmental agencies have been assisted in the achievement of their goals and the improvement of the quality of their organizational offerings via technological developments [1]. Potentially, 
convenience and accessibility of governmental services and information to citizens through the use of technology can be aided [2]. Additionally, technology can help in the decentralization of public administration and in the enhancement of the government's ability to oversee key activities [3]. However, governmental agencies should understand that the implementation of technology, in and of itself, is not sufficient. As such, many organizations recognize that the key to increasing overall effectiveness is the combination of appropriate technology with effective knowledge resource management. Effective knowledge management (KM) is an ever-growing need for government, at all levels [4]. Consequently, the promise of delivering better e-government services and improved performance is causing many governmental organizations to place greater importance on the development of knowledge management systems.

In order for organizations to sustain improved business performance, knowledge has become a vital component [5]. The synergy created by the capacity of information processing integrated with the human capacity for creativity embodies the power of knowledge management to increase the responsiveness and flexibility of an organization [6]. The desire to enhance productivity and efficiency is often the driving force for Information Systems (IS) implementation in the public sector. In fact, KM is shown to be a business enabler in some research [7].

Businesses, government employees, and citizens all benefit from the services that e-government provides. Knowledge-focused approaches deliver more effective services and better representation requiring that e-government possess a wealth of information and knowledge [4]. The motivation for this study lies in the documentation and testing of the importance of technology and knowledge in e-government as it relates to the examination of knowledge management and leadership. The lack of relevant studies related to $\mathrm{KM}$ in public sector e-government also highlights the need for further investigation. Additionally, there is a paucity of quantitative assessment of leadership and KM contributions to e-government, even though leadership is recognized as an important component. The purpose of this study is to develop and conduct preliminary testing on a model that identifies the relationship between leadership and knowledge management in an e-government context. Our findings significantly contribute to the literature beyond the traditional findings about the importance of leadership to KM because we have shown this relationship within the context of the MBNQA model. Using the MBNQA context gives the leadership - KM connection credibility that extends into other fields such as quality and operations management.

\section{Literature Review and Hypotheses Development}

\subsection{E-Government Development}

E-government provides the opportunity to improve traditional government practices by better utilizing information technology to retrieve, store, and disseminate information or to offer services [8]. Knowledge diffusion is a key e-government initiative in spite of the fact that governments around the world have different e-government initiatives [9]. The importance of leaders who champion e-government and who play a crucial role in the development of e-government applications cannot be overstated [10]. Information resources and technology management must be guided by competent leadership. [11]. Thus, leadership has the potential to exert a positive impact by providing direction for 
e-government development and promoting knowledge sharing and transfer within e-government application development.

User satisfaction and user motivation to use online services represent research that has examined relevant issues related to e-government service delivery. Carter and Bélanger [2] examined how technology affects a citizen's intention to use e-government. By applying the Technology Acceptance Model and diffusion theory within an e-government study they find that perceived ease of use, compatibility, and trustworthiness are significant predictors of a citizen's intention to use an e-government service [2].

The role of the local government leadership in the adoption of e-government was investigated by other researchers. Moon and Norris [12] find that adoption of municipal e-government is determined by managerial innovativeness and orientation. Additionally, Moon and Norris find that e-government outcomes are associated with the adoption of e-government, government capacity and institutional characteristics. In conclusion, their findings suggest that managerial innovativeness, managerial orientation, and city size are the most compelling determinants of municipal e-government adoption. Delivering services and information to citizens, government employees, and businesses are also cited by prior works on e-government in relation to the importance of technology. An unexplored area, however, is the role that knowledge management has on e-government success.

\subsection{MBNQA and the Leadership Triad}

One of the most prestigious quality improvement awards is The Malcolm Baldrige National Quality Award (MBNQA). Well recognized in industry, education, healthcare and government, it was established in 1988 by the United States Congress and has been consistently updated to better reflect new theory on quality control and business process improvement. The general theory underlying the MBNQA is that leadership drives the system that creates results [13]. The MBNQA assesses seven sets of criteria including: leadership, strategic planning, customer and market focus, information and analysis, human resource focus, process management, and business results [13]. The validity of the MBNQA has been examined by several prior studies (e.g., $[14,15])$. According to one study, the effective management of an organization and the improvement of its performance and competitiveness are strongly related to information and analysis [12]. IS is also an important component of quality management, along with strategic systems, operational systems, and results according to Curkovic, Melnyk, Calantone, and Handfield [14]. Through the use of cross-validation of the validity of the MBNQA in the manufacturing and service sectors and Prajogo [16] suggests that the only difference between these two sectors is that the service sector has significantly higher scores in people management than the manufacturing sector. By performing cluster analysis based upon the MBNQA criteria and data derived from organizations within the trading, wholesaling and retailing industries, Zhao, Yeung, and Lee [17] found that the type of quality system adopted by an organization is highly associated with organizational factors.

Further studies in the healthcare industry provided additional evidence of the effect that leadership has on every variable in MBNQA model $[19,20]$. The analyses provided by these studies emphasized the philosophy in quality management-leadership drives systems that improve the results. Their works support the contention that proactive leadership enhances the success of an organization. Finally, Wilson and Collier (2000) find that the 1995 MBNQA model contains consistent predictors for organizational 
performance. Leadership results in impacting outcomes via the other categories: process management, human resources, strategic planning and information analysis. Furthermore, the studies show that information and analysis are the second most influential factors in MBNQA model.

Although the MBNQA has continued to evolve over the years, many published studies tested the MBNQA model published prior to 2002. The most recent version of MBNQA consists of a leadership triad, results triad, and measurement, analysis and knowledge management dimensions [18]. The Leadership triad consists of the leadership, strategic planning, and customer/market focus dimensions and emphasizes the importance of a leadership focus on strategy and customers. The Results triad includes the human resource focus, process management, and business results dimensions. Overall, the changes in the underlying MBNQA model are consistent with the philosophical change in quality management theory. The emergence of knowledge management in the MBNQA criteria signifies the importance of knowledge and information in an organization. KM has the potential to embody continuous improvement and the Total Quality Management (TQM) effort such that, in the future, they will not require separate delineation [21]. The performance management system is built upon a foundation of measurement, analysis and $\mathrm{KM}$.

\subsection{Knowledge Management}

Knowledge as applied to business includes various definitions. Some define knowledge as actionable information or data [22] whereas others define knowledge as authenticated information [23] and a justified belief to increase one's capacity for effective action [24,25]). Knowledge has different perspectives: a state of mind, object, a process, a condition of accessing to information, and a capability [21]. Tacit and explicit knowledge represent two specific categories. Tacit knowledge includes intuitions, hunches. Explicit knowledge refers to facts, numbers, and symbols.

According to von Krogh and Kleine (1998), knowledge management (KM) refers to identifying and leveraging the collective organizational knowledge to enhance competitive position. Creation, storage, transfer, and application processes make up an organization's knowledge management framework. Common applications of knowledge management fall into three areas: coding and sharing organization's best practices, the creation of knowledge directories, and the creation of knowledge networks [26].

The knowledge-based theory [28] of an organization posits that organizations improve their efficiency by economizing on knowledge exchange. The existing hierarchies in an organization facilitate knowledge transfer [29]. Cooperative social contexts that are conducive to the creation, coordination, transfer, and integration of knowledge distributed among its employees, business units, and business partners contribute to organizational gain [30].

Technology is an enabler for the process of delivering information and services via e-government and serves to enhance the delivery mechanism [7]. Irani, Sharif, and Love [31] show that mapping and identifying knowledge is useful in the IS evaluation and implementation lifecycle. KM allows acquiring, organizing, and communicating both tacit and explicit knowledge of employees in a systematic manner to improve productivity and effectiveness [26].

The management of knowledge within the context of e-government can not only add value internally, but also externally to business partners or constituents. According to Koh, Ryan, and Prybutok [32] this is an evolutionary path on which government agencies embark as they manage 
knowledge and provide e-government services to their citizenry. The path is delineated into five stages: (1) informational - the main function of e-government is to distribute information to citizens and employees using uncomplicated Web sites; (2) interactional-e-government begins to interact with citizens and employees through e-mail and online forms; (3) transactional-citizens can perform transactions such as paying their water bill via e-government websites; (4) integrated-characterized by a seamless interface that integrates all aspects of e-government processes; and (5) collaborative - knowledge is captured from both internal and external sources. Additionally, some research has suggested that user-centric marketing approaches are keys to moving down this evolutionary path which involves engaging citizens in knowledge creation and collaboration [36]. Other studies have proposed that e-government initiatives can help governmental agencies improve knowledge sharing with the public, but they must be implemented carefully to ensure the quality of processes and services delivered [33,34]. These prior works recognize the knowledge and information technology requirements for e-government.

\section{Research Model}

In an effort to leverage their knowledge resources organizations are turning to knowledge management (KM) initiatives and technologies. Due to the importance of technology and knowledge in e-government, this study examines knowledge management as it relates to the leadership triad within the MBNQA model. Figure 1 shows our research model in which the Leadership Triad is a second order construct that consists of three reflective first-order constructs: leadership, strategic planning and customer and market focus.

Figure 1. Research model.

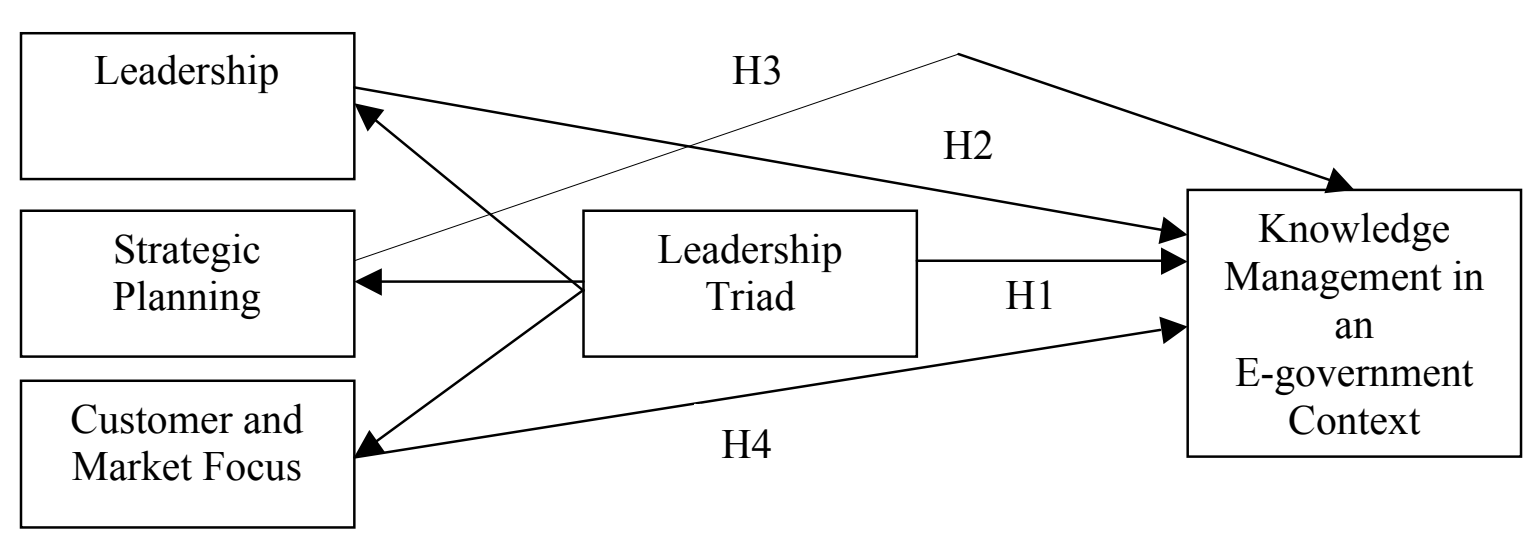

The MBNQA model shows that leadership, strategic planning and customer and market focus are correlated. Theoretical grounds justify the existence of a reflective second order construct - leadership triad. Nickerson and Zenger [35] contend that leadership has a functional role in supporting the generation of knowledge. They propose that an organization should structure itself in a manner that enhances knowledge generation and handling. This idea served as an essential motivation for the city government used in this study in the evaluation of its current structure via the MBNQA survey and pursuit of any necessary changes for the purpose of enhancing its e-government capabilities. The most 
recent MBNQA model posits that the leadership triad is correlated with knowledge management. Thus we propose:

Hypothesis 1: There is a direct positive relationship between the leadership triad and knowledge management in an E-government context.

In examining knowledge portal development within the public sector, Teo [7] finds that top management support and commitment promotes knowledge sharing. In order to prosper, organizations depend on their leadership to drive continuous improvement and constant innovation. According to Fedor et al. [5] there are several key drivers of member performance-related rating which include leadership, knowledge generation, and dissemination. Leadership consistently emerges as associated with good practice and provides focus, direction, vision, coherence, and the ideas that are required to interact with KM systems to deliver better results [37]. Therefore, we propose:

Hypothesis 2: There is a positive relationship between leadership and knowledge management in an E-government context.

One particular concept that is emphasized within the strategic management literature is that knowledge management (KM) provides a competitive advantage. Developing strategic plans requires extensive knowledge of the relevant customers, markets, suppliers, competitors, etc. The strategic management literature suggests that strategy leads to organizing capital and resource allocations that result in superior competitive advantages [38]. A critical source of resource developed within an organization is in fact knowledge [28]. Strategic advantage in competitive environments can be obtained and sustained via KM [39]. The direction of KM is usually dictated by strategy and it is advantageous to align that KM in a manner that is consistent with an organization's strategy [40]. KM is strategic in nature and during this process new competencies are developed for organizations to sustain and compete in a dynamic environment [41]. Consistent with this theory, we posit:

Hypothesis 3: There is a positive relationship between strategic planning and knowledge management in an E-government context.

Knowledge management instruments are employed by many organizations in an effort to enhance their customer relations. Strategy, processes, systems and change management are all important to make knowledge-based customer relationship management initiatives successful, and should be considered by organizations [42]. KM systems capture customer knowledge that allows the development of innovative products or services as well as business process transformation. In addition, building knowledge based effective practices when interacting with customers or markets can effectively leverage relationships with important stakeholders. The improvement of customer relationships by constantly monitoring the customers' behavioral and internal processes is a fundamental concept facilitated by KM [43]. Therefore, organizations with a customer and market focus emphasize KM. We propose:

Hypothesis 4: There is a positive relationship between customer and market focus and knowledge management in an E-government context. 


\section{Methodology}

\subsection{Respondent Organization}

The organization studied in this research is a municipal government in the southwestern United States. The City, which employs 1,110 individuals, is classified as a small-to-medium sized municipality with a population of approximately 115,000 . It was ranked in the top twenty-five of the fastest growing cities in the nation with populations over 100,000 in 2008 and 2009. The City is home to two major universities and thus, the average age is lower than the national average (33.8 years versus 37.8 years). The City requested that the research team help them to evaluate its e-government initiatives in order to enhance the quality and effectiveness of its operations

\subsection{Survey Development}

The research team worked with city government managers in developing and reviewing a survey capturing the MBNQA 2002 framework criteria to test our proposed model. The research team modified Prybutok and Spink's [20] MBNQA instrument, updating the instrument to reflect the 2002 MBNQA criteria from the earlier version used in the Prybutok and Spink study. The instrument was also modified to fit the government sector context of this study. To ensure the appropriateness and content validity of the revisions, first, a group of ten experts with extensive experience in both survey research and quality management reviewed the modified instrument. These experts consisted of five faculty members and five Ph.D. students from MIS, Management Science, and Psychology.

During the instrument development, the research team had lengthy discussions and correspondence with city managers and employees regarding the substance and format of the survey as well as the survey delivery mechanics. Because of their expertise in quality control, a pilot test of the instrument was conducted at a meeting of the Dallas chapter of the American Society for Quality to assess the instrument for content and clarity. The instrument was modified based upon the comments received and the analysis of the pilot study data.

\subsection{Measures}

The KM items used in this survey capture the characteristics of the knowledge management process: knowledge creation, storage, and utilization. The development of these KM items is consistent with Holsapple and Joshi's [44] and O'Dell et al.'s [22] conceptualization of KM. For example, Holsapple and Joshi [44] state that the nature and particular structure of knowledge influence the methods by which it is identified, captured, indexed, stored, disseminated, updated, and disposed of once it becomes obsolete. O'Dell et al. [22] emphasized that the focus of KM should be on getting the right information to the right people at the right time. Specifically, reflecting the knowledge management cycle, we use timely update of explicit knowledge to measure the knowledge creation process, consistency of and review of explicit knowledge to measure the knowledge storage process, and items capturing benchmarking, systematic analysis of performance data internally and externally to measure the knowledge utilization process. The Leadership Triad items measuring leadership, strategic planning, and customer and market focus were adapted from Prybutok and Spink [20] as 
stated above. The final items by construct are shown in Table 1. The range of responses on the Likert scale were from 1 (strongly disagree) to 7 (strongly agree).

Table 1. Survey items to measure Malcolm Baldrige National Quality Award (MBNQA) criteria.

\begin{tabular}{|c|}
\hline ership \\
\hline $\begin{array}{l}\text { 1. CoD has strong values for achieving high quality performance that applies consistently } \\
\text { throughout all facets of the organization (AB1). }\end{array}$ \\
\hline $\begin{array}{l}\text { 2. CoD has good communication channels through which top management's direction (values } \\
\text { and expectations) clearly delivered to employees (AB2). }\end{array}$ \\
\hline $\begin{array}{l}\text { 3. Management of the CoD clearly sets strategy, goals, and objectives for future directions for } \\
\text { the organization (AB3). }\end{array}$ \\
\hline $\begin{array}{l}\text { 4. Management of the CoD establishes and reinforces environment for empowerment and } \\
\text { innovation ( } \mathrm{AB} 4) \text {. }\end{array}$ \\
\hline $\begin{array}{l}\text { 5. Management of the CoD encourages and supports organizational and employee learning } \\
\text { (AB5). }\end{array}$ \\
\hline $\begin{array}{l}\text { 6. CoD evaluates performance and capabilities of all functions of the organization on a regular } \\
\text { basis (AB6). }\end{array}$ \\
\hline $\begin{array}{l}\text { 7. CoD uses recent performance review findings as feedback for improvement and innovation } \\
\text { opportunities (AB7). }\end{array}$ \\
\hline $\begin{array}{l}\text { 8. Management in CoD is concerned with the impact on society of our products, services, or } \\
\text { operations (AB8). }\end{array}$ \\
\hline $\begin{array}{l}\text { 9. CoD actively supports and strengthens our relationships with key segment of the community } \\
\text { (such as education, community service organizations, religious organizations, or } \\
\text { professional associations) (AB9). }\end{array}$ \\
\hline 2. Strategic Planning \\
\hline $\begin{array}{l}\text { 10. CoD has a well-defined short-term (1-2 years) plan to help achieve its goals and objectives } \\
\text { (AB10). }\end{array}$ \\
\hline $\begin{array}{l}\text { 11. CoD has a well-defined long-term (2-5 years) plan to help achieve its goals and objectives } \\
\text { (AB11). }\end{array}$ \\
\hline $\begin{array}{l}\text { 12. CoD has a well-defined strategy/plan to increase Customer/citizen/citizen satisfaction } \\
\text { (AB12). }\end{array}$ \\
\hline $\begin{array}{l}\text { 13. CoD has well-defined human resource requirements and plans which consider employees' } \\
\text { capabilities and needs (AB13). }\end{array}$ \\
\hline 14. CoD has a well-defined strategy/plan to enhance supplier/partner relationships (AB14). \\
\hline 15. CoD has well-defined strategy/plan to address key goals and objectives (AB15). \\
\hline $\begin{array}{l}\text { 16. CoD employs performance measures or indicators for tracking progress relative to its action } \\
\text { plans (AB16). }\end{array}$ \\
\hline 17. CoD allocates resources well to ensure accomplishment of overall action $\mathrm{pl}$ \\
\hline
\end{tabular}


Table 1. Cont.

\section{Customer and Market Focus}

1. CoD has a formal method for determining current product/service requirements and expectations of its Customer/citizens/citizens (AB18).

2. CoD has a formal method for determining future product/service requirements and expectations of its Customer/citizens/citizens (AB19).

3. CoD has a formal method for identifying Customer/citizen/citizen groups and market segments (AB20).

4. CoD has effective Customer/citizen relationship practices that enable Customer/citizens/citizens to seek assistance, comments, or complaints (AB21).

5. CoD continuously improves its Customer/citizen/citizen relationship management practices (AB22).

6. CoD determines key Customer/citizen/citizen contact requirements and delivers them to all employees involved in the response chain (AB23).

7. CoD resolves Customer/citizen/citizen complaints promptly and effectively (AB24).

8. CoD formally examines Customer/citizen/citizen complaints in order to make necessary improvements to its processes (AB25).

9. CoD measures and analyzes current levels of Customer/citizen/citizen satisfaction and dissatisfaction (AB26).

10. CoD compares its Customer/citizen satisfaction results with similar organizations (AB27).

\section{Knowledge Management}

CoD provides effective performance measurement systems and techniques for ensuring each of the following (28-32):

11. Data and information reliability (AB 28)

12. Data and information consistency (AB29)

13. Data and information accessibility (AB30)

14. Data and information review (AB31).

15. Timely update of data and information (AB32)

16. CoD regularly performs comparisons of its performance to similar world-class organization benchmarks in order to support its performance, evaluation, and improvement (AB33).

17. Performance data and information gathered internally is systematically analyzed to help support overall quality objectives (AB34).

18. Performance data and information gathered externally is systematically analyzed to help support overall quality objectives (AB35).

*Note: CoD stands for the city that was surveyed.

\subsection{Survey Administration}

Our model examines how the leadership triad components effect KM enabled e-government effectiveness. Because employees have an understanding about government operations, familiarity with organizational knowledge creation, storage, sharing, and utilization processes, screening complaints, and maintaining systems, their judgment about these issues are relevant and useful. 
Because citizens are unfamiliar with internal government operations and the knowledge creation cycle and, given the purpose of our study, we chose not to include them.

The target population of our survey was 1,110 employees of a city government. Via email, we requested that the employees participate in our on-line survey regarding e-government initiatives. Two weeks after the initial email, a follow up email was sent. The survey was available to employees for five weeks. A total of 339 responses were recorded, representing a 30.82\% response rate. However, $20 \%$ of those responses contain incomplete data and were discarded from further analyses, leaving 178 useful responses. We examined nonresponse bias by comparing the demographics variables of age, gender, educational level, and years of experience of the respondents with those of the population. No significant differences were found.

\section{Results}

\subsection{Demographics}

The number of male and female respondents is split about evenly. The city's workforce has a range of ages, but $67.3 \%$ of the respondents are between $30-49$ years old. The city's employees are relatively well educated, with about half having a four-year degree or higher and another $25.5 \%$ having some college. Seventy-two percent have been in their current position for less than five years and $43 \%$ have less than five years of experience in total. Details of the demographics are shown in Table 2.

Table 2. Demographics.

\begin{tabular}{|l|c|}
\hline \multicolumn{1}{|c|}{ Category } & Percentage \\
\hline Gender & \\
\hline Male & 50.6 \\
\hline Female & 49.4 \\
\hline Age & 0.6 \\
\hline Less than 20 & 13.0 \\
\hline 20-29 & 34.9 \\
\hline $30-39$ & 32.4 \\
\hline $40-49$ & 17.6 \\
\hline $50-59$ & 1.5 \\
\hline $60+$ & \\
\hline Highest Education Level & 12.7 \\
\hline High school & 25.5 \\
\hline Some college & 12.4 \\
\hline 2-year college & 29.3 \\
\hline 4-year college & 20.1 \\
\hline Graduate school & \\
\hline Years at current job & 23.6 \\
\hline Less than one year & 16.8 \\
\hline 1-less than 2 years & 10.9 \\
\hline 2-less than 3 years & 12.4 \\
\hline 3-less than 4 years & 8.3 \\
\hline 4-less than 5 years & \\
\hline & \\
\hline & \\
\hline & \\
\hline & \\
\hline & \\
\hline & \\
\hline & \\
\hline
\end{tabular}


Table 2. Cont.

\begin{tabular}{|l|c|}
\hline \multicolumn{1}{|c|}{ Category } & Percentage \\
\hline Years at current job & 8.6 \\
\hline 5-less than 7 years & 5.0 \\
\hline 7-less than 10 years & 9.4 \\
\hline 10-less than 15 years & 3.8 \\
\hline 15-less than 20 years & 1.2 \\
\hline 20 years or over & 13.9 \\
\hline Years of Experience & 8.6 \\
\hline Less than one year & 21.2 \\
\hline 1-less than 2 years & 20.1 \\
\hline 2-less than 5 years & 14.2 \\
\hline 5-less than 10 years & 13.0 \\
\hline 10-less than 15 years & 9.1 \\
\hline 15-less than 20 years & \\
\hline
\end{tabular}

\subsection{The PLS Structural Equation Model}

We used Partial Least Squares analysis (PLS) to analyze our data. PLS is an extension of Ordinary Least Squares regression and seeks to determine a best fit relationship between multiple predictor variables and a result. In PLS, $\mathrm{R}^{2}$ and substantial/significant structural paths are used to evaluate the model fit [45]. PLS is an appropriate method for testing the proposed model because of the minimal demands on measurement scales, sample size, and residual distributions [45,46]. Although the MBNQA model was validated by some studies, the revised version with a KM component is new, and was not tested in prior works. Consistent with the exploratory nature of the KM in the MBNQA model, it is appropriate to use PLS.

The MBNQA model is built upon a set of interrelated core values and concepts [21,18]. Consistent with previous theoretical and empirical work, we modeled the leadership triad as a second-order construct, consisting of three first-order reflective constructs: leadership, strategic planning, and customer and market focus. We first evaluate the measurement model and then validate the structural model.

\subsubsection{Assessing the Measurement Model}

Reliability assesses whether are dependable, stable, and free from error [47]. Table 3 shows that all composite reliabilities are greater than 0.9 , higher than the recommended value of 0.7 [48]. 
Table 3. Descriptive statistics.

\begin{tabular}{|c|c|c|c|}
\hline & Mean & Std. Deviation & Composite Reliability \\
\hline Leadership Triad & & & 0.96 \\
\hline Leadership & 4.92 & 1.24 & 0.94 \\
\hline Strategic Planning & 4.58 & 1.20 & 0.93 \\
\hline Customer and Market Focus & 4.63 & 1.21 & 0.92 \\
\hline Knowledge Management & 4.33 & 1.33 & 0.92 \\
\hline
\end{tabular}

Convergent validity is the extent to which items load on the construct they purport to measure [7]. Table 4 shows all the factor loadings and t-statistics for factor loadings. In general, factor loadings greater than 0.7 are considered consistent with good convergent validity. Almost all of the loadings for leadership, strategy, customer and market focus, knowledge management, and the leadership triad are greater than 0.7 and statistically significant.

Table 4. Loadings.

\begin{tabular}{|c|c|c|}
\hline & Original & T-Statistic \\
\hline Leadership & & \\
\hline AB1 & 0.81 & 25.75 \\
\hline AB2 & 0.81 & 27.75 \\
\hline AB3 & 0.86 & 40.37 \\
\hline AB4 & 0.81 & 23.18 \\
\hline AB5 & 0.81 & 24.17 \\
\hline AB6 & 0.79 & 23.26 \\
\hline AB7 & 0.72 & 14.91 \\
\hline AB8 & 0.77 & 17.54 \\
\hline AB9 & 0.71 & 16.69 \\
\hline Strategy & & \\
\hline AB10 & 0.82 & 30.73 \\
\hline AB11 & 0.84 & 39.66 \\
\hline AB12 & 0.82 & 28.44 \\
\hline AB13 & 0.73 & 16.67 \\
\hline AB14 & 0.61 & 8.65 \\
\hline AB15 & 0.87 & 29.88 \\
\hline AB16 & 0.75 & 17.66 \\
\hline AB17 & 0.78 & 24.19 \\
\hline Customer & & \\
\hline AB18 & 0.73 & 16.31 \\
\hline AB19 & 0.76 & 15.56 \\
\hline AB20 & 0.69 & 11.12 \\
\hline AB21 & 0.74 & 19.00 \\
\hline & & \\
\hline
\end{tabular}


Table 4. Cont.

\begin{tabular}{|c|c|c|}
\hline AB22 & 0.82 & 26.47 \\
\hline AB23 & 0.79 & 22.11 \\
\hline AB24 & 0.72 & 17.96 \\
\hline AB25 & 0.79 & 25.69 \\
\hline AB26 & 0.77 & 17.93 \\
\hline $\mathrm{AB} 27$ & 0.56 & 9.25 \\
\hline \multicolumn{3}{|l|}{ LT } \\
\hline AB1 & 0.74 & 18.30 \\
\hline $\mathrm{AB} 2$ & 0.72 & 20.22 \\
\hline AB3 & 0.79 & 23.56 \\
\hline AB4 & 0.73 & 17.54 \\
\hline AB5 & 0.73 & 18.31 \\
\hline AB6 & 0.73 & 19.08 \\
\hline AB7 & 0.71 & 15.27 \\
\hline AB8 & 0.73 & 17.38 \\
\hline AB9 & 0.68 & 14.87 \\
\hline AB10 & 0.76 & 23.13 \\
\hline AB11 & 0.76 & 25.80 \\
\hline $\mathrm{AB} 12$ & 0.78 & 23.83 \\
\hline AB13 & 0.72 & 17.49 \\
\hline AB14 & 0.56 & 8.55 \\
\hline $\mathrm{AB} 15$ & 0.81 & 23.46 \\
\hline AB16 & 0.70 & 19.18 \\
\hline AB17 & 0.75 & 19.78 \\
\hline $\mathrm{AB} 18$ & 0.70 & 12.46 \\
\hline AB19 & 0.71 & 11.23 \\
\hline $\mathrm{AB} 20$ & 0.59 & 8.70 \\
\hline $\mathrm{AB} 21$ & 0.65 & 13.32 \\
\hline AB22 & 0.74 & 18.72 \\
\hline AB23 & 0.75 & 23.08 \\
\hline AB24 & 0.66 & 13.96 \\
\hline $\mathrm{AB} 25$ & 0.71 & 15.93 \\
\hline AB26 & 0.67 & 13.28 \\
\hline $\mathrm{AB} 27$ & 0.48 & 8.19 \\
\hline \multicolumn{3}{|l|}{ KM } \\
\hline AB33 & 0.67 & 10.14 \\
\hline AB34 & 0.76 & 20.38 \\
\hline AB35 & 0.77 & 20.88 \\
\hline AB29 & 0.84 & 27.49 \\
\hline AB30 & 0.84 & 29.75 \\
\hline AB31 & 0.87 & 31.46 \\
\hline AB32 & 0.81 & 25.43 \\
\hline
\end{tabular}


Correlations between theoretically similar measures should be high (reflect a strong relationship) while correlations between theoretically dissimilar measures should be low (reflect a weak relationship). Higher factor loadings are associated with strong evidence that the measures with which they are associated represent the underlying constructs. We examined the square root of Average Variance Extracted (AVE) for each construct and found that in each case it was greater than 0.7, higher than the recommended value of $0.5[45,48]$ (see Table 5).

Table 5. Construct correlations and Square Root of AVE.

\begin{tabular}{|c|c|c|}
\hline & LT & KM \\
\hline LT & 1 & \\
\hline KM & 0.73 & 1 \\
Square Root of AVE & 0.71 & 0.80 \\
\hline
\end{tabular}

Discriminant validity is the extent to which constructs are distinct. Discriminant validity requires that measures do not correlate too highly with measures from which they are supposed to differ. Table 5 shows items to construct correlations and the bold numbers show that items correlate higher to their theoretical assigned construct than the other constructs, thus, supporting discriminate validity.

Table 6. Item to constructs correlation table.

\begin{tabular}{|c|c|c|c|c|c|}
\hline & leadersh & strategy & customer & LT & KM \\
\hline AB1 & $\mathbf{0 . 8 5}$ & 0.65 & 0.58 & 0.74 & 0.49 \\
\hline AB2 & $\mathbf{0 . 8 1}$ & 0.62 & 0.55 & 0.72 & 0.50 \\
\hline AB3 & $\mathbf{0 . 8 5}$ & 0.74 & 0.58 & 0.79 & 0.53 \\
\hline AB4 & $\mathbf{0 . 7 5}$ & 0.66 & 0.56 & 0.73 & 0.47 \\
\hline AB5 & $\mathbf{0 . 7 8}$ & 0.64 & 0.58 & 0.73 & 0.50 \\
\hline AB6 & $\mathbf{0 . 7 7}$ & 0.65 & 0.58 & 0.73 & 0.47 \\
\hline AB7 & $\mathbf{0 . 7 3}$ & 0.65 & 0.58 & 0.71 & 0.49 \\
\hline AB8 & $\mathbf{0 . 7 9}$ & 0.67 & 0.59 & 0.73 & 0.42 \\
\hline AB9 & $\mathbf{0 . 6 2}$ & 0.63 & 0.55 & 0.68 & 0.41 \\
\hline AB10 & 0.63 & $\mathbf{0 . 8 2}$ & 0.62 & 0.76 & 0.59 \\
\hline AB11 & 0.63 & $\mathbf{0 . 8 4}$ & 0.62 & 0.76 & 0.58 \\
\hline AB12 & 0.70 & $\mathbf{0 . 8 2}$ & 0.67 & 0.78 & 0.53 \\
\hline AB13 & 0.71 & $\mathbf{0 . 7 3}$ & 0.57 & 0.72 & 0.53 \\
\hline AB14 & 0.38 & $\mathbf{0 . 6 1}$ & 0.52 & 0.56 & 0.49 \\
\hline AB15 & 0.69 & $\mathbf{0 . 8 6}$ & 0.66 & 0.81 & 0.56 \\
\hline AB16 & 0.54 & $\mathbf{0 . 7 5}$ & 0.60 & 0.70 & 0.52 \\
\hline AB17 & 0.72 & $\mathbf{0 . 7 8}$ & 0.61 & 0.75 & 0.55 \\
\hline AB18 & 0.66 & 0.62 & $\mathbf{0 . 7 3}$ & 0.70 & 0.52 \\
\hline AB19 & 0.64 & 0.67 & $\mathbf{0 . 7 6}$ & 0.71 & 0.56 \\
\hline AB20 & 0.48 & 0.52 & $\mathbf{0 . 6 9}$ & 0.59 & 0.37 \\
\hline AB21 & 0.45 & 0.53 & $\mathbf{0 . 7 4}$ & 0.65 & 0.44 \\
\hline AB22 & 0.57 & 0.60 & $\mathbf{0 . 8 2}$ & 0.74 & 0.53 \\
\hline AB23 & 0.64 & 0.65 & $\mathbf{0 . 7 9}$ & 0.75 & 0.51 \\
\hline AB24 & 0.55 & 0.53 & $\mathbf{0 . 7 2}$ & 0.66 & 0.40 \\
\hline & & & & & \\
\hline
\end{tabular}


Table 6. Cont.

\begin{tabular}{|c|c|c|c|c|c|}
\hline & leadersh & strategy & customer & LT & KM \\
\hline AB25 & 0.59 & 0.60 & $\mathbf{0 . 7 9}$ & 0.71 & 0.51 \\
\hline AB26 & 0.51 & 0.58 & $\mathbf{0 . 7 7}$ & 0.67 & 0.52 \\
\hline AB27 & 0.30 & 0.45 & $\mathbf{0 . 5 6}$ & 0.48 & 0.45 \\
\hline AB28 & 0.47 & 0.57 & 0.47 & 0.54 & $\mathbf{0 . 8 8}$ \\
\hline AB30 & 0.52 & 0.59 & 0.50 & 0.59 & $\mathbf{0 . 8 7}$ \\
\hline AB31 & 0.44 & 0.59 & 0.49 & 0.57 & $\mathbf{0 . 9 1}$ \\
\hline AB32 & 0.44 & 0.59 & 0.45 & 0.55 & $\mathbf{0 . 8 6}$ \\
\hline AB33 & 0.32 & 0.44 & 0.56 & 0.51 & $\mathbf{0 . 6 4}$ \\
\hline AB34 & 0.49 & 0.59 & 0.68 & 0.64 & $\mathbf{0 . 7 0}$ \\
\hline AB35 & 0.49 & 0.55 & 0.67 & 0.62 & $\mathbf{0 . 6 7}$ \\
\hline
\end{tabular}

\subsubsection{Assessing the Structural Model}

We also used PLS to assess the structural model. All the path coefficients in the model in Figure 2 are statistically significant at the 0.001 level. The loadings of the three first-order constructs, Leadership, Strategic Planning, and Customer/Market Focus are 0.92, 0.90, and 0.94, respectively, greater than the 0.70 recommended by Chin [45]. This provides evidence that the leadership triad is an appropriate second-order construct. The coefficient from the leadership triad to knowledge management is 0.7 , significant at 0.001 level.

Figure 2. Path model.

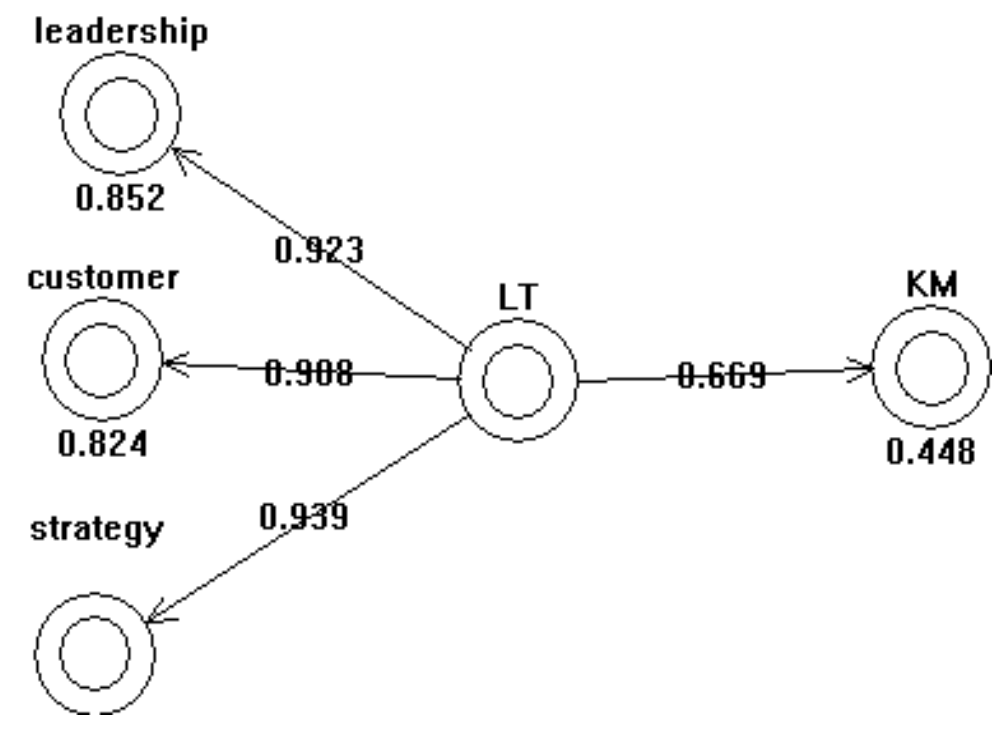

\section{Discussion and Conclusion}

The statistical significance of our model supports the role that leadership plays in knowledge management within an e-government context. Our model shows that the leadership triad is a meaningful categorization of three important components of the MBNQA, and that these components are relevant in an e-government environment. The first triad component, leadership, articulates top management's goals, values and expectations. Ways in which leadership is manifested in a practical 
manner include: stressing the importance of high quality performance through performance review feedback, supporting organizational and employee learning and innovation, and ensuring that the functional capabilities of the organization are evaluated on a regular basis.

The second triad component, strategic planning, ensures that plans are well defined to achieve the organization's goals and objectives. This includes assessing the internal human resource requirements and external supplier/vendor relationships needed to meet those goals and objective. Implementing measures or indicators for tracking progress relative to action plans are an important part of the strategic planning process.

The third triad component is customer and market focus. To truly be market focused, there must be formal methods for determining current and future requirements and expectations of citizens. This includes incorporating practices that allow citizens to seek assistance, make comments, or to complain. Procedures must be in place to deal with these promptly and effectively and to make certain that the right employees are involved in the response chain.

E-government initiatives place a high importance on IT that facilitates effective KM. In this study we explore the significance of leadership in utilizing technologies to manage knowledge in the delivery of electronic public services. The data, gathered at a city government, empirically supports our model that proposes the importance of various aspects of leadership in managing knowledge in an e-government environment.

We provided the results of this study via a written report and an oral presentation to the City's key leaders. In doing so, we stressed the importance of our findings that leadership, strategic planning, and a customer and market focus are significant factors leading to knowledge management in an e-government environment. Our findings imply that robust leadership, demonstrated by effectively communicating the goals, values and expectations of e-government initiatives is needed. Strategic planning processes that formally define strategic short term (1-2 years) and longer term (3-5 years) plans are required. In addition, careful attention must be paid to investigating, evaluating and implementing e-government solutions that will meet current and future requirements of the customers, that is, the citizenry.

\subsection{Practical Implications}

The City has implemented a variety of e-government applications. Their initial foray into e-government entailed applications to disseminate knowledge about selected city services. Electronic knowledge directories were also made available online so that citizens that could easily determine how to contact experts in a variety of areas. Subsequently, transaction-based customer service applications were added to the e-government services available to citizens. For example, citizens can pay utility bills or court fines electronically. The City also created an interactive mapping system that maps local attractions, restaurants, and city service locations using a geographical information system (GIS).

\subsection{Conclusion}

In conclusion, this research is a valuable step in filling the void in which the relationship between leadership and KM is empirically assessed in an e-government context. Our study found that three aspects of the MBNQA leadership triad, leadership, strategic planning, and a customer/market focus, lead to effective knowledge management. While the implementation of technology helps governmental 
agencies in providing additional services to the public, the implementation of technology alone is insufficient. Governmental agencies are realizing that the combination of information technology and effective knowledge management practices are required to obtain superior results. As a result, many governmental organizations are placing greater emphasis on the development of knowledge management systems so that they can more effectively serve the citizenry. Our results highlight the key role that leadership plays in these efforts.

\section{References}

1. Anderson, E.A.; Adams, D.A. Evaluating the success of TQM implementations: Lessons from employees. Prod. Inv. Manage. J. 1997, 38, 1-6.

2. Carter, L.; Bélanger, F. The utilization of e-government services: Citizen trust, innovation and acceptance factors. Inform. Syst. J. 2005, 15, 5-25.

3. Ma, L.; Jongpil; C.; Thorson, S. E-government in China: Bringing economic development through administrative reform. Gov. Inform. Q. 2005, 22, 20-37.

4. Harman, C.; Brelade, S. Knowledge, e-government and the citizen. Knowl. Manage. Rev. 2001, 4, 8-13.

5. Fedor, D.B.; Ghosh, S.; Caldwell, S.D.; Maurer, T.J.; Singhal, V.R. The effects of knowledge management on team members ratings of project success and impact. Decision Sci. 2003, 34, 513-539.

6. Zhang, D.; Zhao, J.L. Knowledge management in organizations. J. Database Manage. 2006, 17, $1-8$.

7. Teo, T.S.H. Meeting the challenges of knowledge management at the housing and development board. Decis. Support. Syst. 2005, 41, 147-159.

8. Brueckner, A. E-Government II best practices for digital government. Bulletin of America Society of Information Science and Technology 2005, 31, 16.

9. Andersen, K.V.; Beck, R.; Wigand; R.T.; Bjùrn-Andersen, N.; Brousseau, E. Information Polity 2004, 9, 217-232.

10. Streib, G.D.; Willoughby, K.G. Local governments as e-governments: Meeting the implementation challenge. Public Admin. Quart. 2005, 29, 78-110.

11. McClure, D.L.; Kearney, A.T. Strategic information technology and the CEO agenda. AT Kearney Publications: Chicago, IL, USA, 2000.

12. Moon, M.J.; Norris, D.F. Does managerial orientation matter? The adoption of reinventing government and e-government at the municipal level. Inform. Syst. J. 2005, 15, 43-60.

13. Wilson, D.D.; Collier, D.A. An empirical investigation of the Malcolm Baldrige National Quality Award causal model. Decision Sci. 2000, 31, 361-390.

14. Curkovic, S.; Melnyk, S.; Calantone, R.; Handfield, R. Validating the Malcolm Baldrige National Quality Award framework through structural equation modeling. Int. J. Prod. Res. 2000, 38, 765-791.

15. Prybutok, V.; Zhang, X.; Peak, D. Assessing the effectiveness of the Malcolm Baldrige National Quality Award model with municipal government. Socio. Econ. Plan. Sci. 2011, 45, 118-129.

16. Prajogo, D.I. The comparative analysis of TQM practices and quality performance between manufacturing and service organizations. Int. J. Serv. Ind. Manag. 2005, 16, 217-228. 
17. Zhao, X.; Yeung, A.C.L.; Lee, T.S. Quality management and organizational context in selected service industries of China. J. Oper. Manag. 2004, 22, 575-587.

18. Malcolm Baldrige National Quality Awards Performance Excellence; NIST: National Institute of Standards And Technology: Washington, DC, USA, 2011; Available online: http://www.nist.gov/ baldrige/publications/archive/2009_2010_business_nonprofit_criteria.cfm (accessed on 29 November 2011).

19. Douglas, T.J.; Fredenall, L.D. Evaluating Deming Management Model of total quality in services, Decision Sci. 2004, 35, 393-422.

20. Prybutok, V.R.; Spink, A. Transformation of a health care information system: A self-assessment survey. IEEE T. Eng. Manage. 1999, 46, 299-310.

21. Adamson, I. Knowledge management-The next generation of TQM? Total Qual. Manag. Bus. 2005, 16, 987-1000.

22. ODell, C.; Elliot, S.; Hubert, C. Achieving knowledge management outcomes. In Handbook on Knowledge Management: 2. Knowledge Directions; Hosapple, C.W., Ed.; Springer: Heidelberg, Germany, 2003; pp. 253-287.

23. Dretske, F. Knowledge and the flow of information. MIT Press: Cambridge, MA, USA, 1981.

24. Huber, G. Organizational learning: Contributing processes and the literature. Organ. Sci. 1991, 2 , 88-115.

25. Nonaka, I. A dynamic theory of organizational knowledge creation. Organ. Sci. 1994, 5, 14-37.

26. Alavi, M.; Leidner, D.E. Review: Knowledge management and knowledge management systems: Conceptual foundations and research issues. MIS Quarterly 2001, 25, 107-136.

27. Von Krogh, G.; Kleine, D. Future research into knowledge. In Knowing in Organizations; von Krogh, G., Roos, J., Kleine, D., Eds.; Sage Publications: Thousand Oaks, CA, USA, 1998; pp. 26-66.

28. Conner, K.R.; Prahalad, C.K. A resource based theory of the organization: Knowledge versus opportunism. Organization Sci. 1996, 7, 477-501.

29. Nahapiet, J.; Ghoshal, S. Social capital, intellectual capital and the creation of value in firms. Acad. Manage. Proc. 1997, 11, 35-39.

30. Ghoshal, S.; Moran, P. Bad for practice: A critique of Transaction Cost Theory. Acad. Manage. Rev. 1996, 21, 13-47.

31. Irani, A.; Sharif, A.M.; Love, P.E.D. Linking knowledge transformation to information systems evaluation. Eur. J. Inform. Syst. 2005, 14, 213-228.

32. Koh, C.E.; Ryan, S.; Prybutok, V.R. Creating value through managing knowledge in an e-government to constituency (G2C) environment. J. Comput. Inform. Syst. 2005, 45, 32-41.

33. Kiu, C.; Yuen, L.; Tsui, E. Semantic interoperability for enhancing sharing and learning through e-government knowledge-intensive portal services. Journal of E-Governance 2010, 33, 108-116.

34. Rawajbeh, M.A.; Haboush, A. Enhancing the e-Government Functionality using Knowledge Management. WASET 2011, 75, 393-397.

35. Nickerson, J.A.; Zenger, T.R. A knowledge-based theory of the organization-The problem-solving perspective. Organization Sci. 2004, 15, 617-632.

36. Kolsaker, A. Understanding E-government $(\mathrm{G} 2 \mathrm{C})$ in the knowledge society. Int. J. Inform. Technol. \& Manage. 2007, 6, 1. 
37. Capshaw. S.; Koulopoulos, T.M Knowledge Leadership. Information Management: New York, NY, USA, 1999. Available online: http://www.dmreview.com/article_sub.cfm?articleId=20 (accessed on 28 November 2011).

38. Chandler, A.D. Jr. Strategy and Structure. MIT Press: Cambridge, MA, USA, 1962.

39. Kankanhalli, A.; Tan, B.C.Y.; Wei, K.K. Understanding seeking from electronic knowledge repositories: An empirical study. JASIST 2005, 56, 1156-1166.

40. McElroy, M. Cutting-edge methods to align KM with company strategy. KM Review 2005, 7, 4.

41. Nielsen, B.B. Strategic knowledge management research: Tracing the co-evolution of strategic management and knowledge management perspectives. Competitiveness Review 2005, 15, 1-13.

42. Salomann, H.; Dous, M.; Kolbe, L.; Brenner, W. Rejuvenating customer management: How to make knowledge for, from and about customers work. EMJ 2005, 23, 392-403.

43. Sin, L.Y.M.; Tse, A.C.B.; Yim, F.H.K. CRM: Conceptualization and scale development, EJM 2005, 39, 1264-1290.

44. Holsapple, C.W.; Joshi, K.D. Organizational knowledge resources. Decis. Support. Syst. 2001, 31, 39-54.

45. Chin, W.W. Issues and opinion on structural equation modeling. MIS Quarterly 1998, 22, 7-16.

46. Gopal, A.; Bostrom, R.P.; Chin, W.W. Applying adaptive structuration theory to investigate the process of group support systems use. J. Manage. Inform. Syst. 1993, 9, 45 -69.

47. Kerlinger, F.N.; Lee, H.B. Foundations of Behavioral Research, 4th ed.; Harcourt Brace: Fort Worth, TX, USA, 2000.

48. Fornell, C.; Larker, D.F. Evaluating structural equation models with unobservable variables and measurement error. J. Marketing Res. 1981, 18, 39-50.

(C) 2012 by the authors; licensee MDPI, Basel, Switzerland. This article is an open-access article distributed under the terms and conditions of the Creative Commons Attribution license (http://creativecommons.org/licenses/by/3.0/). 